\title{
Towards a Kantian Phenomenology of Hope
}

\author{
Deryck Beyleveld • Paul Ziche
}

Accepted: 16 January 2015 / Published online: 8 February 2015

(C) The Author(s) 2015. This article is published with open access at Springerlink.com

\begin{abstract}
The aim of this paper is to examine the extent to which Kant's Critique of the Power of Judgment (CPoJ) can be, or otherwise ought to be, regarded as a transcendental phenomenology of hope. Kant states repeatedly that $C P O J$ mediates between the first two Critiques, or between the theoretical knowledge we arrive at on the basis of understanding and reason's foundational role for practical philosophy. In other words, exercising the power of judgment is implicated whenever we try to bring together the ethical issue of strictly determining our actions on the one hand and the necessity to act in the physical world on the other. We will argue that this mediating function is properly understood only if the ideations produced by self-understanding are characterized as objects of rationally required hope or fear.
\end{abstract}

Keywords Kant $\cdot$ Hope $\cdot$ Judgment $\cdot$ Faith $\cdot$ Philosophy of Religion $\cdot$ Epistemology

\section{Introduction: Kant's Critique of the Power of Judgment's Mediation Between Reason and Understanding}

At least one strand of Kant's position in the Critique of the Power of Judgment (CPOJ) may be summarized as follows: pure reason in its practical application requires agents to accept the moral law, which requires them to consider that they have free will (as the necessary condition, the 'ratio essendi', for the existence of the moral law) and also that there is a final end (the summum bonum, happiness distributed in exact proportion to virtue - the possibility of the attainment of which requires it to be assumed that God exists and that agents are immortal). ${ }^{1}$ At the same time, pure reason in its theoretical application requires agents to accept that every

\footnotetext{
${ }^{1}$ In quoting works from Kant, we follow the usual conventions: references to the Critique of Pure Reason (CPuR) are given with the A/B-references to the first resp. second edition; other works by Kant are referred to on the basis of the Academy edition of the Gesammelte Schriften (Kant 1900 sqq.), stating volume and page number. Translations are given according to the Cambridge Edition of the Works of Immanuel Kant (Kant 1995 sqq.).
}

Paul Ziche's research is supported by a grant from NWO (Netherlands Organisation for Scientific Research) whose support is gratefully acknowledged.

D. Beyleveld

Durham Law School, Durham University, Durham, UK

e-mail: deryck.beyleveld@durham.ac.uk

D. Beyleveld $\cdot$ P. Ziche $(\bowtie)$

Department of Philosophy and Religious Studies, University of Utrecht, Utrecht, The Netherlands e-mail: p.g.ziche@uu.nl 
event has a cause (the law of nature). So, unless what finally ought to happen can happen in accordance with the law of nature, pure theoretical reason and pure practical reason are not in harmony; and such harmony can only exist if the final end is the purpose of nature. Since pure reason cannot be thought to be in contradiction with itself, harmony between pure theoretical reason and pure practical reason must be supposed. But the concept of a purposiveness of nature is not a concept of pure theoretical reason, nor is it an idea of pure practical reason. Instead, it is provided by the power of judgment, which is independent of practical reason. As such, in mediating between the theoretical and the practical, it enables, indeed, requires, belief (faith) that the final end is possible, and not merely that it ought to be possible.

So read, $C P O J$ differs from the earlier Critiques in identifying and designating the power of judgment as having an autonomous role from the powers of understanding and reason in the way in which 'Understanding' or 'Reason' (which terms Kant often interchangeably uses to designate the collective powers of the mind by which humans are capable of self-awareness, as well as to designate specific sub-faculties of the mind) grounds theoretical, aesthetic and moral claims. By so doing, and by assessing the powers and limits of the faculty of judgment, which requires an examination of the beautiful, the sublime and teleology, Kant claims to have better explained, and thus secured, his faith in the existence of God.

Self-understanding might well require us to accept the moral law, the summum bonum might well be a postulate of the moral law, and God's existence might well be necessary for the summum bonum to be achieved. But will it be achieved, or is it even possible for it to be achieved? What Kant thinks understanding the power of (reflective) judgment shows is that it is a requirement of self-understanding for an agent to represent nature as if it were organized in accordance with the purposes of an intelligent cause (God) and that this cannot be questioned intelligibly (see 5:397-404).

We claim in this paper that the function of the power of judgment is crucially important for getting Kant's ethical ideas to work, and requires all the ideations ${ }^{2}$ of Reason to be characterized as referring to objects of rationally required hope (whereas Kant confines this status to happiness under the summum bonum), where to be rationally required is to be a necessary condition of human self-understanding, and hope is defined in the following way:

'A hopes that Q is the case' means 'A desires $\mathrm{Q}$ to be the case and (with the idea of $\mathrm{Q}$ being the case in mind) considers it to be possible for $\mathrm{Q}$ to be the case in the sense that $\mathrm{A}$ neither believes that $\mathrm{Q}$ is the case nor that $\mathrm{Q}$ is not the case. ${ }^{3}$

We claim no more for this concept than that it is phenomenologically adequate in describing a way in which persons do and can relate to objects that they have a positive attitude towards (see Beyleveld 2012), and that it resonates with how Kant characterizes hope.

This paper has three parts. In Part 1, we explain why the concept of hope is central to understanding the thesis of $C P O J$ that it is the power of judgment that - through mediating between the understanding and reason - renders the moral law apodictically certain and, consequently, belief in God rationally necessary. In Part 2, we examine Kant's concepts of faith and hope and various other concepts that he introduces to elucidate the epistemic status of various ideations of Reason, and argue that it is the ideation of 'hope' that is best suited to perform the role Kant assigns to the power of judgment. In Part 3, we focus on problems with

\footnotetext{
${ }^{2}$ We use the term 'ideation' neutrally to cover thought-products related to the understanding, the power of judgment, or reason. Kant, not always consistently, confines concepts to the understanding and ideas to reason. ${ }^{3}$ Compare the definition in Axinn (1994), 193-200. His definition differs from ours in a more knowledge- (more precisely: ignorance-) related analysis of the epistemic attitude inherent in hope, and by placing more constraints on our ability to describe the desired situation Q.
} 
the idea that 'faith' best performs this role, and suggest that $C P O J$ should be reconstructed as a transcendental phenomenology of hope, which is to say that all the ideations connected with the moral law (free will, God, immortality, the summum bonum) should be seen as objects of rationally required hope

\section{$2 \mathrm{CPoJ}$ and Establishing the Moral Law}

Kant does not characterise the ideations of Reason in terms of hope. His explicit view, presented in the Critique of Practical Reason $(C P r R)$ and followed and expanded in CPoJ is that free will is proved to exist (shown to be real) in being the condition (ratio essendi) of the moral law, which is an apodictic law of practical reason. As such, free will is the

keystone of the whole structure of a system of pure reason, even of speculative reason; and all other concepts (those of God and immortality), which as mere ideas remain without support in the latter [i.e., in speculative reason], now attach themselves to this concept. (5:3-4)

Unlike free will, the existence of God and of immortality are not conditions of the moral law but conditions of applying the moral law to the summum bonum, which is the necessary object (final end) of the moral law. Though

we cannot affirm that we cognize and have insight into [...] [the ideas of God and immortality,] [...]; by means of the concept of freedom objective reality is given to the ideas of God and immortality and a warrant, indeed a subjective necessity (a need of pure reason) is provided to assume them, although reason is not thereby extended in theoretical cognition. $(5: 4-5)$

In other words, the existence of (e.g.,) God (and henceforth, we will concentrate on God) is a postulate of pure practical reason (see 5:124-134), meaning that 'it is morally necessary to assume the existence of God' (5:125); or that the moral law is the 'ground of a maxim of assent [to the existence of God] for moral purposes' (5:146). In still other words, God is an object of pure practical rational belief (see, e.g., 5:144-146) or 'faith', as he puts it in CPOJ (see especially $5: 471-473$ ). But it must not be thought that we have a moral obligation to believe in God, for 'a belief that is commanded is an absurdity' (5:144). Faith in God is not an

affirmation $[\ldots]$ to which we hold ourselves to be obligated, but one which we assume for the sake of an aim in accordance with the laws of freedom [...] as adequately grounded in reason (although only in regard to its practical use) for that aim. (5:472)

These statements need further explanation, particularly with regard to their systematic foundation in Kant's philosophy. Clearly, theoretical philosophy is insufficient to support them. And they are far from clear, for Kant definitely holds that the apodictic certainty of the moral law provides grounds for belief in God that outweigh any considerations (or the lack of them) derivable from theoretical reason (see 5:472). At the same time, Kant cannot simply mean that practical reason takes over where theoretical reason fails: it is far from clear that there is any kind of smooth transition between these faculties that would make such an operation of replacement possible. It is at just this juncture that CPoJ commands our attention.

At the end of his Introduction to $C P O J$, Kant says that the human mind has three faculties those of cognition, feeling (of pleasure and displeasure), and the faculty of desire. The faculty of cognition, itself, has three sub-faculties or capabilities: understanding, power of judgment, 
and reason, each of which 'contains' a 'constitutive' distinctive type of a priori principle with a distinctive sphere of application corresponding to a specific faculty of the mind. Thus, understanding characterizes the faculty of cognition as such and contains a principle of lawfulness applied to nature; the power of judgment ('independent of concepts and sensations that are related to the determination of the faculty of desire' [5:196-197]) characterizes the faculty of feeling and contains a principle of purposiveness applied to the experience of beauty and to the special laws dealing with natural things and events; while reason constitutes the faculty of desire and contains a principle of the final end applied to freedom (see 5:196-198).

If $C P O J$ may be said to have an overarching thesis it is that

the power of judgment, provides the mediating concept between the concepts of nature and the concept of freedom, which makes possible the transition from the purely theoretical to the purely practical, from lawfulness in accordance with the former to the final end in accordance with the latter, in the concept of a purposiveness of nature; for thereby is the possibility of the final end, which can become actual only in nature and in accord with its [nature's] laws, cognized. (5:196)

How does this mediation occur? What Kant says about 'the common human understanding', which consists of those cognitive powers that are 'the least that can be expected from anyone who lays claim to the name of a human being' (5:293) - so (in effect) those cognitive powers required for one to be aware of one's own existence - is illuminating. The common human understanding is governed by three maxims of reasoning:

1. To think for oneself; 2. To think in the position of everyone else; 3 . Always to think in accord with oneself. [...] The third maxim, namely that of the consistent way of thinking $[\ldots]$ can only be achieved through the combination of the first two [...]. One can say that the first of these maxims is that [sic] maxim of the understanding, the second that of the power of judgment, the third that of reason. (5:294-295)

As far as thinking in the position of everyone else is concerned, it consists of setting oneself 'apart from the subjective private conditions' of one's own judgment, and reflecting on this judgment 'from a universal standpoint' by putting oneself 'into the standpoint of others' (5:295).

In his Logic (9:57), Kant refers to these maxims as 'general rules and conditions for avoiding error', so they apply to theoretical, aesthetic and practical reasoning or thinking. Since he holds that the moral law is a fact of pure reason and God is an idea of reason postulated by the moral law, it is particularly pertinent to look at these maxims in application to practical reasoning. We suggest that, so viewed, the first requires agents to adopt a broadly internalist viewpoint. I, an agent, must only accept practical precepts (maxims) if they are acceptable to me on the basis of what I personally (subjectively) value. The second maxim requires me to have values that any agent must espouse. This is because the exercise of the reflective power of judgment requires me to recognize that I cannot be the particular agent that I am (constituted, at least in part, by my personal values and choices) unless I am an agent, i.e., unless I have the capacities of the common human understanding, the cognitive faculties of the human mind that are necessarily shared by all agents. So, I cannot obey the first maxim unless my personal values are acceptable to me as an agent per se. This requires me to reason from the universal viewpoint of all agents, the viewpoint of an agent qua being an agent per se. Consequently, pure reason requires maxims in accord with the first maxim to be consistent with values that every agent must choose. However, the maxim of reason generated by rendering the maxims of the understanding and the power of judgment consistent is, surely, none other than the categorical imperative as expressed by Kant's Formula of Universal Law: 
$[A]$ ct only in accordance with that maxim through which you can at the same time will that it become a universal law. (4:421)

In $C P r R$, Kant tells us that consciousness of pure practical laws (moral laws), which is a fact of reason, is made possible for us

by [our] attending to the necessity with which reason prescribes them to us and to the setting aside of all empirical conditions to which reason directs us. The concept of a pure will arises from the first, as consciousness of a pure understanding arises from the latter. (5:30)

If we read what reason prescribes to us as the generation of the maxim of reason, and the setting aside of all empirical conditions as the operation of the reflective power of judgment, then the implication is that the moral law is given to us as the fact of reason in the processes of self-reflection that underpin Kant's three maxims of the common human understanding. Indeed, on this basis, despite the popularity of views to the contrary, Kant's argument for the moral law in Groundwork of the Metaphysics of Morals (GMM) is identical to his argument in $C P r R$. For, in GMM, Kant says that 'a human being' inherently

finds in himself a capacity by which he distinguishes himself from all other things, even from himself insofar as he is affected by objects, and that is reason (4:452)

and

the rightful claim to freedom of will made even by common human reason is based on the consciousness and the granted presupposition of the independence of reason from merely subjectively determining causes (4:457)

on the basis of which agents must think of themselves as belonging to the world of understanding as well as to the world of sense, and though Kant here refers to 'reason' this duality is forced upon agents by what in $C P O J$ is designated as the reflective power of judgment.

In our opinion, when Kant says that the moral law/the categorical imperative is a synthetic a priori proposition, he means that it is one that an agent must accept on pain of failing to understand what it is to be an agent (see 4:420 coupled with 4:426). His argument that the moral law is given to us as the fact of pure reason (see 5:29-31) is simply that, given that understanding, the power of judgment and reason are the capacities that enable self-understanding, exercising these capacities consistently with each other requires acceptance of the moral law as the Formula of Universal law.

Now, supposing all this is so, what makes the question of hope central to CPoJ? Well, in Logic, Kant says that the field of philosophy may be summed up in the following questions:

1) What can I know? -

2) What ought I to do?

3) What may I hope?

4) What is man?

Metaphysics answers the first question, morals the second, religion the third, and anthropology the fourth. Fundamentally, however, we could reckon all of this as anthropology, because the first three questions relate to the last one. $(9: 25$; cf. $C P u R$ A804-805/B832-833) 
It is clear that $C P u R$ deals with the first question and $C P r R$ deals with the second. In a letter to Stäudlin in 1793, Kant says that it is in Religion Within the Boundaries of Mere Reason that his question 'What may I hope?' is finally worked out, and that this question amounts to, as he adds between brackets, a 'philosophy of religion' (quoted in Peters 1993, 15). While this is true if we depict the answer to the first question as finally worked out in The Metaphysical Foundations of Natural Science, and the answer to the second question as ultimately worked out in The Metaphysics of Morals, the position of hope within Kant's philosophy differs from that of the objects of knowledge and the imperatives of reason. Kant not only addresses the third question in all three of his Critiques, his answer to it concludes all three Critiques. In all three works, what I may hope for is addressed in the context of Kant's moral argument for God; issues concerning hope, therefore, may be said to integrate the three Critiques, which integration Kant claims is the systematic function of $C P O J$. The reason Kant consistently gives as to why I must assume that God exists, is that God must exist for it to be possible for the summum bonum (the state of affairs in which all will receive their just deserts in relation to their moral virtue), which is postulated by the moral law, to be brought about. In a nutshell, Kant claims that I must assume that God exists because the apodictic necessity of the moral law entails that I must hope that it is possible that I (all) will receive happiness in proportion to my (their) virtue, and God's existence is necessary for this hope to be realistic.

\section{Faith, Hope and Related Epistemic Concepts in Kant}

\subsection{Faith and Hope Between Theoretical and Practical Philosophy}

'Hope', therefore, needs to be related both to issues concerning knowledge and to practical ideas. When we do so, we discover a distinctive epistemic signature of 'hope' that distinguishes it from both knowledge and faith. While faith in God is certain,

no one will be able to boast that he knows that there is a God and a future life; for if he

knows that, then he is precisely the man I have long sought (A 828-9/B 856-7)

(but whom, or so one would have to supplement this passage, one cannot, and should not be able, to find). Kant discusses this difference at length in the section on 'opinion, knowing, and believing' (where 'believing' stands for the German 'Glaube', which is better translated as 'faith') in the methodological chapter at the end of CPuR. The basic epistemological framework of this discussion is the same for faith and knowledge. In both cases, we deal with specific forms of 'taking something to be true', and in both cases it is towards propositional contents such as the existence of God and immortality that we adopt the epistemic attitude of 'taking to be true' (A 820/B 848). As such, faith is a direct replacement for knowledge in cases where knowledge itself cannot be obtained. But hope is not, for it presupposes that I am ignorant, or at least undecided, as to whether what I hope for is real or not, and knowledgereplacement operations cannot overcome this type of ignorance or uncertainty (for an analysis of forms of ignorance in the context of Kant's philosophy of hope, see Axinn (1994), 165-181, 248). What, then, are the important differences that make Kant ask 'What may I hope?' in place of 'What can $/ \mathrm{may}^{4} \mathrm{I}$ have faith in?'?

Kant introduces the notion of hope in the context of our prospects of achieving happiness in the future - more precisely, of achieving happiness earned by acting morally. This suggests

\footnotetext{
${ }^{4}$ Note that it is not directly evident which modality fits here; one might also consider that we must have faith in, for instance, the existence of God.
} 
that arguments based upon hope fall under what Kant calls the 'primacy of practical reasoning' (5:119-121), and are employed where our theoretical resources are insufficient. What one may call the official doctrine in these matters is pretty straightforward: all operations going beyond theoretical knowledge - the key topic of the methodologies of CPuR and $C P O J$ alike - can bring about an extension of our knowledge only 'with respect to practical reason' (e.g., $5: 133){ }^{6}$ However, Kant's notion of hope does not seem to fit the picture of purely practical transgressions of the critical bounds of knowledge in at least two ways: hope does not always lead to fully specified or characterized outcomes (see section 2.2), yet hope remains importantly related to issues in theoretical philosophy.

In the very same sentence in which Kant defines hope as being directed towards happiness, he declares that the practical necessity to assume moral principles can be equated with the theoretical necessity that requires us to hope that we can earn happiness by morally good behaviour (A 809/B 837). In this equation, the question 'What may I hope?' is not only both practical and theoretical, it also has a clear direction towards the realm of the theoretical

so that the practical leads like a clue [in the German original, it reads 'nur als ein Leitfaden', as 'nothing but a clue'/'only as a clue'; note also that a 'Leitfaden' is more than just a hint: it guides one to a discovery] to a reply to the theoretical question, and, in its highest form, the speculative question. (A 805 / B 833)

This connection is confirmed in a number of passages. Two examples will suffice. In $C P u R$ (A 809/B 837), Kant distinguishes between reason in its practical usage and a theoretical usage of reason, and it is in the latter context that we must assume that 'everyone has cause to hope for happiness in the same measure as he has made himself worthy of it in his conduct'. In Religion, hope is explicitly related to the discovery - following the guideline of 'natural miracles' - of 'new laws of nature', while genuine miracles destroy our confidence in our theories of natural phenomena (6:88; 'hope' being emphasized in this passage by Kant himself).

This provides a genuine challenge. It is important to emphasize again that, though referring to issues in theoretical philosophy, these passages do not provide a strategy for smoothly extending the domain of possible knowledge beyond its theoretical limitations. ${ }^{7}$ Hope's functioning like knowledge does not imply that we indeed have knowledge when we have hope. Hope is more clearly theoretically directed than postulates and hypotheses, but on the other hand, hope only allows weaker conclusions to be drawn than those possible on the basis these other notions. If I am required to postulate the existence of God, I must act as if He exists; if I must hope that happiness can be achieved, this only implies acting as if happiness could possibly be brought about. ${ }^{8}$

\footnotetext{
${ }^{5}$ The status of the methodological considerations in $C P r R$ is, at least at first sight, different from that in the other two Critiques: in moral philosophy, methodology is concerned with the question of how practical reason can be made subjectively effective $(5: 151)$. It would be worthwhile to explore how this question relates to the more traditional methodological discussions on subjective vs. objective forms of cognition in the other two Critiques. ${ }^{6}$ One has, therefore, to conclude - together with the editors of the Academy edition - that the Second Critique $(5: 132)$ contains a Freudian typo when Kant omits a 'nicht' in the phrase 'erweitern also zwar das spekulative Erkenntnis' (otherwise, the 'aber' in the next clause would be incomprehensible). Freudian typos are frequent in the Third Critique with its frequent switches between 'Teleology' and 'Theology'.

${ }^{7}$ When Wiesche (2012, e.g. 59) emphasizes that the 'intermediary epistemic status [epistemische Zwischenstellung]' of hope results from the primacy of practical reason, this, in the light of the passages just quoted, precisely misses the intermediary status of hope between the theoretical and practical dimensions of human reason. - Cf. also Wimmer (1990, e.g. 75-6) on the necessity to (more clearly than in Kant's oeuvre itself) distinguish between the moral and religious tenets in Kant.

${ }^{8}$ Cf. Beyleveld (2012) on the necessity of sharpening Kant's phrase in A 806/B 834: the important point about hope is not that it implies an argument leading from 'something should happen' to 'something is', but only to 'something should be'.
} 


\subsection{Hope and Epistemic Openness}

Hope's epistemic status is remarkable. While clearly being a key concept in Kant's systematic enterprise, hope requires us to adopt an open epistemic attitude. While hypotheses, for instance, can play a role in explanations, no such explanatory power, according to Kant, can be derived from hope - this weakness, however, is compensated by hope's ability to establish systematic unity. This may be put in modal terms. I can only hope for what is not impossible, but being so directed is not sufficient for being in a state of hoping. We need to attach a positive value to what our hope is directed towards as well as presupposing a form of indeterminacy on the epistemological level: hope requires dubiety, a questioning, as against an affirmative, stance ${ }^{9}$; we cannot know, in the sense of having determined concepts, what we are going to get when we pursue what hope is directed towards. This sets arguments involving hope apart from the forms of an 'extension of pure reason' as discussed in $C P r R$. The key problem there is how concepts that go beyond what can be given in intuition can attain 'objective reality', i.e., how these concepts can be treated just like ordinary concepts that arise in theoretical cognition. Kant argues in a way that rather smoothly extends our ordinary forms of knowledge. A concept such as 'God', when considered empirically, remains a 'not precisely determined concept' (5:139), but when considered practically, it can be thus determined. But this is not the case with Kant's prototypical objects of hope: hoping that we can achieve future happiness does not tell us more about what this happiness will consist in - beside the bare fact that is the object of hope, namely that it will be a form of happiness that is deserved on moral grounds - and the same holds with regard to the systematic unity of the special laws or nature. While having faith in the existence of God, or accepting immortality as a matter of postulates, extends our knowledge in the sense that we both accept the content of these claims and also have a conceptually fixed picture as to what it is that we thus accept, this does not seem to be the case with the typical objects of hope.

Hope needs to be triangulated very carefully here. While I can only hope for what is not in itself, and that on theoretical grounds, impossible, I may wish for the impossible, or accept an article of faith despite its absurdity. On the other hand, hoping is different from assuming that something is the case or will be the case (i.e., from expecting it): while hypotheses claim the status of being (unproved, yet possible) propositions from which further theoretical argument can depart, this is impossible for both faith and hope. This holds, as it were, both upwards and downwards: the claims of hope cannot be derived via theoretical deduction, and they provide no basis for further such deductions.

Let's work out the difference between faith and hope, within a Kantian framework, in some more detail. ${ }^{10}$ First, as regards their respective objects, Kant distinguishes, though without much argument, between their objects. The prototypical object of hope in Kant's Critiques, future happiness, is not a matter of faith/postulates, while immortality is (which raises the question as to how immortality, as an object of faith/postulates, and future happiness relate to each other). The important difference on this level is that faith, but not hope, is directed towards objects or certainties that already hold here and now; they lie, as Kant frequently states, 'in the world'. ${ }^{11}$ Closely related is the fact that hope is tensed in a way that is different

\footnotetext{
${ }^{9}$ Stratton-Lake $(1993,67)$ analyses Kant's notion of hope in terms of an 'infinite striving', an approximation that never exhausts what it is directed towards. This does not seem adequate for the positive connotations that hoping conveys. Better suited is Wiesche's $(2012,57)$ characterization of hope in terms of a 'kontrafaktisches Gelingen'. ${ }^{10}$ Also interesting are some passages in Struggle of the Faculties (7:43) where Kant states that hope becomes alive in us through faith. This is a clear two-step account that gives hope a function that is different from that of faith; cf. also 7:42 on 'hope and fear'.

${ }^{11}$ In the relevant passages in $C P O J$, this phrase is regularly attached to the summum bonum, (see, e.g., 5:435, 447).
} 
from both faith and postulates (cf. Beyleveld 2012; Stratton-Lake 1993). Hope is 'subjectively future', while faith is 'subjectively present'. A last point here: typical forms of knowledgetransgressing reasoning, such as the framing of hypotheses or analogical reasoning, are inadequate for dealing with the supersensible. In $\S 90$ of $C P O J$, Kant maintains that the framing of hypotheses fails here because any hypothesis requires confirmation or falsification via sense-experience. The same argument is pressed against analogical reasoning (5:464-5). ${ }^{12}$ While there are other ways of going beyond our established knowledge that do not pronounce mere possibilities (both postulates and faith are explicitly about the supersensible, but are pronounced as certain), hope is directed to what is viewed as merely possible while still being able to be directed towards the supersensible. The insufficiency of theoretical reasoning to provide access to the supersensible has further implications. A successful way of accessing the supersensible cannot be a matter of probabilities (see 5:465, and most explicitly 5:400: 'Probabilities count for nothing here', see also A822/B850). This, then, will also hold for hope regarding the supersensible.

Secondly, there is a difference in the degree to which the objects of faith and hope, respectively, come to be conceptually determined by taking the attitudes of faith and hope towards them. To be sure, it is possible to state that I hope that a very specific event is going to happen, but this does not seem to capture the essence of hope in the Kantian picture. When I state that I hope that the sun is going to shine tomorrow, this is not essentially different from wishing (when it has been raining all day today) that this is going to happen. But Kant clearly distinguishes hope from wishing (see 6:117). If we can only rely on our own human resources, we can only wish for happiness. But hoping is closely related (though not identical) to expecting a future event. Only when a superhuman power is introduced - and that is what Kant's arguments concerning hope are intended to establish - can we go beyond wishing and achieve a state of expectation $(6: 482) .^{13}$

Take another example (discussed in detail in Beyleveld 2012): When I express the hope that my friend has caught her train on time, I am not only stating that I am ignorant as to whether she did or not, and at the same time expressing my desire that she did; I am also engaging in a consideration or exploration of alternative scenarios. Without compromising my ignorance about the actual course of events, I consider alternative options for what might have happened. Even where hope is about a concrete event or object, and very clearly so in those cases where the object of hope is not conceptually determined, hope is fundamentally directed towards what we may call a framework ${ }^{14}$ : We need not know what a happy life feels like or what this implies in terms of concrete features; it is sufficient to be directed, in the attitude of hope, towards a framework that inherently leaves open that/how it will be filled in. Put simply: expecting can be seen as a state of believing that something will happen whether or not it is desired; hoping is a state of considering that something that will satisfy one's desire might happen, and wishing involves no commitment to something actually or possibly happening but merely desiring it.

\footnotetext{
${ }^{12}$ Maly (2012 e.g. 108-113) strongly emphasizes the 'otherness' involved in Kant's discussion of symbolic modes of cognition.

${ }^{13}$ See also 5:452: What the 'righteous man' - Spinoza is the stock example - cannot have is an 'expectation' that nature and purposes are going to harmonize. Still, hope does not become identical to expectation; and another interesting comparison can be made with 'Trost', 'comfort', which Kant explicitly links to hope (6:76), but to which he also denies certainty.

${ }^{14}$ See also Axinn (1994) who needs to further differentiate his original statement that in order to hope we need to able to mention a 'description of a certain situation' (193) in the sense that being able to 'construct a schema' is also sufficient for hope (195). This is because the methodological terms 'construction' and 'schema' do not exactly fit the epistemic constraints under which hope operates.
} 
All of this can be given a more nuanced analysis in the epistemological terms used by Kant himself, even though he never devotes an explicit discussion to these terms. Hypotheses are introduced in order to serve as a basis for an explanation (5:466; 5:126). Explanations are (see $5: 411)$ deductions of conclusions from given presuppositions. So, what the hypothesis assumes must be understood clearly and distinctly. Since matters of faith, 'Glaubenssachen', cannot be clarified via sensory intuitions, they cannot form the basis for an explanation. Faith is, as Kant states, a basis for 'comprehensibility' (5:126, see also 6:118). This term, which is not given a clear technical meaning in Kant's critical philosophy, ${ }^{15}$ is also used in the methodological sections of $\mathrm{CPOJ}$ where Kant discusses alternatives for explanatory modes of reasoning. In this respect, too, hope and faith are closely related: what I can only hope for is also unable to serve as the basis for deductions, and needs consequently to be analyzed in terms of 'rendering something comprehensible' or 'intelligible' rather than 'allowing the derivation of knowledge claims'. Hope, in this context, has a clearer systematic position than faith. While matters of faith are indeed, to some extent at least, conceptually determined, this is not the case for hope. The ambiguity inherent in faith - determining its concepts, to some extent at least, but still not allowing for deductions - is avoided in the notion of hope. Hope is unable to function as a premise in deductions not only because of its being related to moral ideals, but also because of its epistemic openness.

\subsection{New Epistemic Options}

It is striking to see how deeply this openness is built into Kant's epistemic vocabulary. One example: In almost all the key passages where he deploys the notion of hope, Kant also employs the less spectacular, but epistemologically equally interesting term of a 'Leitfaden' (which may be translated literally as a 'guideline' or 'guiding thread', Ariadne's thread providing secure guidance in a maze). ${ }^{16}$ Take some examples: In $C P O J$ \$70, where Kant discusses the 'antinomy' of the power of judgment, it is precisely the reflective, and not constitutive/determining character of the power of judgment that requires us to accept a mere 'Leitfaden' as sufficient, and Kant translates this immediately into a statement to the effect that we can 'only hope' that nature forms a unity under empirical laws (5:386). The same terminology is used in $\S 89(5: 460)$; the passage has already been stated: when we relate hope not to the practical realm, but to reason in its theoretical usage, we again get a 'Leitfaden'.

Kant offers a number of possible equivalents for this term. In $C P O J \$ 72$, he distinguishes forms of reasoning along a 'Leitfaden' from investigations into a first origin (5:389). This said,

\footnotetext{
${ }^{15}$ The notions of 'Deutlichkeit' and 'Verständlichkeit' are dealt with in Kant's lectures and writings on logic (see Breitenbach 2009, 171-2). Kant distinguishes between a 'logical' clarity which is brought about by determining concepts, and an 'aesthetic' clarity, based upon intuitions and conveyed by examples, and termed 'understandibility'/'Verständlichkeit' (9:62; the Cambridge translation renders the German 'verständlich' differently in different texts). Logical and aesthetic clarity do not coincide. Breitenbach emphasizes the necessity to combine both forms of clarity in coming to judgments about nature. - Both conceptual modes of understanding and 'symbolic representation' (6:171) are described by Kant as ways of making statements comprehensible.

${ }^{16}$ CPuR regularly proceeds along the 'Leitfaden der Kategorien'. - Grimm's (Grimm 1885) dictionary views 'Leitfaden' as a term of the 18th century that, however, is an insignificant addition to the German language since this word, given its evident mythological background, was readily understandable from the very first moment when it was adopted, and required no explanatory efforts. It is noteworthy, however, that it was related to methodological ideas on more than one level; 'Leitfaden' was, as one of the first occurrences in the writings of Lessing (quoted in Grimm) reminds us, broadly used for introductory guidebooks. Förster $(2002,335)$ discusses the problem that, within the framework of $C P O J$, the 'idea' of an organism cannot guide the investigation, but that a grasp of the complete complexity of what an organism can be needs to precede all further investigation. He relates this argument to yet another dimension of the semantic field of 'Leiten', by referring to Goethe's usage of the concept of a 'Ladder'/'Leiter'.
} 
there remain two options for understanding what a 'Leitfaden' might be: it can be subjectively valid, which makes it 'nothing but a maxim of the power of judgment', or it can be an objective principle of nature. This immediately gives us two alternative renderings: maxim and principle. In neither case does a 'Leitfaden' itself amount to genuine knowledge. A 'Leitfaden' is not aimed at producing theoretical knowledge: what it gives us is - as Kant states in the same $§ 72$ (5:390) of CPoJ in surprisingly open terms - an 'Ahnung'. This term is notoriously difficult to translate. The Cambridge translation offers 'presentiment', but 'intimation' might be an alternative translation, both capturing the fact that 'Ahnung' goes beyond traditional conceptions of rational explanation. 'Ahnung' comes coupled with a 'Wink' ('hint'/“clue') that it might be possible to go beyond a purely natural/naturalistic study of nature in terms of (mechanical) causality. A 'Leitfaden' is a method, but not a method geared towards deriving specific results; it is a method that only claims that we can get a certain type of result (such as, in the context of $C P O J$, nature's being ordered as a realm of purposes), but it does not point towards what we get in the process of investigating nature along this 'Leitfaden'. Kant further explicates this notion (5:398) by stating what a Leitfaden is aimed at, namely at the conducting of research ('nachforschen'), i.e., the mere possibility of investigating nature in its organic objects ('if we would even merely conduct research among its organized products by means of continued observation'). The 'Leitfaden' has - again just like hope - a twofold object: the compatibility of two forms of causality, teleological and mechanical, and the possibility of transcending theoretical reasoning. Although a 'Leitfaden' is a 'mere Leitfaden', not constituting knowledge in itself, it remains within the domain of pure reason, and is not affected by issues concerning probabilities.

Kant introduces an astonishing variety of epistemological terms (see also Guyer 1996, 3641, on Kant's 'Moral epistemology' in $\mathrm{CPoJ}^{17}$ ) in order to characterize the operations that are made possible and required by thinking in terms of 'Leitfäden': 'come to know'/'kennen lernen' (5:400), becoming 'intelligible'/'verständlich' (5:413), being 'indicated'/'angezeigt' (5:412), 'clue' and 'presentiment'/'Wink' and 'Ahnung', 'elucidation'/'Erörterung' (5:412). A clear taxonomy of these epistemic notions is still a desideratum. ${ }^{18}$ The better-studied notions like 'postulates', 'hypotheses', 'analogies', 'symbolic cognition', and also 'faith' itself are only the most prominent forms of cognitive operations that Kant introduces and have to be further specified by relating them to their terminological context.

Kant consistently opposes these operations to 'explaining'. What 'explanation' means is sufficiently clear: logical deduction from first principles that we know clearly and distinctly. The other terms comprise a large variety of options and operations; some are directed more towards future discovery ('indicate', 'presentiment', 'clue'), some are concerned more with modes of organizing knowledge we already have, or of organizing data in a way that renders them comprehensible (making 'intelligible'). The latter term is particularly interesting because Kant opposes it explicitly to 'explaining' (5:412, with an added difficulty because Kant uses two different terminological alternatives for 'explanation', namely 'deduction' and 'explication'). The passage on 'elucidation'/'Erörterung' follows the pattern that has emerged repeatedly already: where no deduction from clearly conceived principles is possible, we need recourse to other epistemological strategies such as 'elucidating'. This, however, also changes

\footnotetext{
${ }^{17}$ In his discussion of the connection between a system of nature, and a system of freedom in Kant, Guyer uses notions from the semantic field of 'hope' (such as 'encouragement', Guyer 2005, 22) together with epistemic notions such as 'assume' or 'suppose' (20) that are in need of further clarification.

${ }^{18}$ Maly (2012), an enormously precise and detailed analysis of the role of symbolic cognition in Kant, does not really compare this type of cognition with other cognitive modes. Breitenbach's (2009) book on the analogy between reason and nature, likewise, does not give a comprehensive typology of forms of knowledge extensions; but see her remarks on the 'Deutlichkeit und Verständlichkeit der Natur' (171-2).
} 
the subject matter we are discussing. This passage is not so much about an alternative mode of epistemic access as about the compatibility of two different modes or two different explanatory maxims. If they are to be in harmony, this must necessarily be by reference to a higher, supersensible principle; and this must no longer be argued within the framework of explanatory deduction. Hope, as a theoretical operation, is a way of discovering. This characterization of hope manages to combine the theoretical impossibility of having knowledge with the positive optimism of being able to arrive at insight. ${ }^{19}$

\section{Towards a Transcendental Phenomenology of Hope?}

If our analysis thus far is sound then it indicates that it is in terms of 'hope' and the related novel epistemic concepts Kant introduces that we can combine theoretical and practical reason in a way that yields a strategy for positively dealing with the limitations of knowledge Kant identifies, and at the same time compensate for these limitations by appealing to results derived from practical reason. In short, the status to be accorded to transcendent objects (free will, God, immortality, the summum bonum) is that their existence is something that we rationally ought to hope for.

But, as we have seen, this is not what Kant does. Of these objects, it is only the summum bonum that we rationally ought to hope for. The other objects are portrayed as objects of rationally required faith. According to Kant, the moral law is given to us as the undeniable fact of pure reason, on the basis of which the existence of free will (being the ratio essendi for the moral law) must be equally undeniable as must be hope for the summum bonum. Then, because the intelligibility of hope for the summum bonum requires the possibility of the summum bonum, which requires the existence of God and immortality (i.e., God and immortality are ratio essendi for the summum bonum), the propositions that God exists and that we are immortal are rendered as undeniable as the moral law.

But giving a different epistemic status to the summum bonum from that given to the existence of God and immortality is extremely problematic. For one thing, if God (for Kant an omnipotent wholly just being) exists, then we rationally ought not merely to be able to hope for the summum bonum, we rationally ought to believe that it will be brought about. The idea that it might possibly not be brought about contradicts the idea that an omnipotent wholly just being exists. So, if understanding that we are categorically bound by the moral law requires us to have faith in God, then it also requires us to have faith, not merely hope, in the summum bonum. Conversely, if all we can derive from the rational necessity of acceptance of the moral law is that we can/ought to hope for the summum bonum, then all we can derive is that we ought to hope that God exists and that we are immortal. This point can be put slightly differently: in reasoning that we can/ought to hope for the summum bonum, Kant seems to reason that the unity of theoretical and practical reason requires us to hold that the summum bonum ought to exist (i.e., it would be an absolutely good thing for it to exist). But, on this basis, it follows only that God ought to exist and that we ought not to believe that it is impossible that God exists. Also, if (as Kant has it in CPrR, 5:4-5) the presupposition of free will (FW) grounds (is sufficient reason for) faith in the existence of God and immortality (G\&I), and free will is the necessary condition for the moral law (ML), then must not God and

\footnotetext{
${ }^{19}$ Note also that the impossibility of arriving at a naturalistic explanation of natural purposes and the fact that natural products therefore are to be considered contingent is, for Kant, a crucial step in his argument that we should investigate those purposes (it is in these contexts that he uses the term 'nachforschen' that is so closely related to hope) on the basis of the power of judgment in its reflective usage $(5: 398)$.
} 
immortality be necessary conditions for the moral law, too? This is because if 'ML entails FW' (entailed by 'not-FW entails not-ML') and 'FW entails G\&I' then'not-G\&I entails not-ML'.

Matters are not helped by maintaining that faith (not mere hope) in the existence of the summum bonum is required. If I believe that the summum bonum will necessarily be brought about then will this not alter my motivation to obey the moral law? There will no longer be any virtue in my obeying the law. I will not obey it because it is the law, but because I believe that punishment is inevitable if I disobey it. And should not Kant concur, for he holds that knowledge that God exists would damage moral motivation in this way (see 5:147)? To be sure, Kant would disagree, because he holds that faith in God does not negate virtue, and it is surely his belief that this is so that explains his claim in CPuR that he has denied knowledge of God in order to create room for faith (see B xxx). But Kant is wrong, simply because what distinguishes faith from theoretical knowledge for him is not the certain truth of the belief that God exists but only the grounds we have for affirming this certain truth, and it is not the certain truth of the belief or the grounds for its acceptance, but the acceptance of it as being certainly true that does the motivational damage (see Beyleveld 2012, 31).

The problematic nature of Kant's reasoning can also be shown by reflection on the architectonic of his three maxims of the common human understanding. Kant, here, views the moral law as a categorical imperative, as generated by the rational requirement to render observance of the maxim of the understanding consistent with observance of the maxim of the power of judgment. The way in which he interprets this has the following results: that aspect of myself in which I am the same as all other agents, which I must recognize on the basis of the power of judgment, revealed by abstracting from all my particular individuating characteristics, is thought of as giving me access to my noumenal or 'proper' self (see, e.g., 4:457), which he refers to as 'homo noumenon' in The Metaphysics of Morals, and homo noumenon is thought of as giving the moral law to homo phaenomenon (myself as the particular agent that I am) $(6: 239,335)$. This accords with the fact that Kant thinks of the moral law as a law of nature for a being possessing the characteristics of homo noumenon, which is a being with free will unaffected by heteronomous incentives, and with his claim that the moral law only appears as a categorical imperative to homo phaenomenon (4:444-445).

This is odd for at least two reasons. First, architectonically, it makes the moral law the law of the power of judgment, and free will the object of the power of judgment rather than of reason as Kant consistently has it (see, e.g., 5:198). Second, since free will is ascertained by abstraction from the contingencies that constitute homo phaenomenon, it makes it difficult to see how a law governing homo noumenon can govern homo phaenomenon. The response that I cannot be the particular agent that I am without being an agent is not sufficient, unless coupled with the recognition that I cannot be an agent without being the particular agent that I am (see Beyleveld 2013a), simply because, as Bernard Williams has pointed out, I cannot be a rational agent and no more (see Williams 1985, 63). Related to this, to see the categorical imperative as an application of the moral law that is the law of the nature of such an abstraction, especially when faith in my immortality is to be seen to follow from recognition of my freedom, surely implies that there is no need for a law to protect my value.

This second reason, we suggest, goes to the heart of the matter. The maxim of reason needs to be interpreted in such a way as to render the other two maxims consistent with each other, not by subordinating the maxim of understanding to the maxim of the power of judgment, and this can only be done by according the ideations of understanding and the power of judgment the same epistemic status.

A strategy that follows this up has a precise place in the history of post-Kantian philosophy: the account that Fichte (1978) gives of how we acquire knowledge about the world integrates will and cognition, activity and receptivity, and gives this integration an anthropologically 
plausible foundation. My idea that there is a world that exists apart from my awareness of such a world arises from my awareness that I cannot infallibly predict what the content of that awareness will be, and especially that I cannot infallibly determine what my experience will be simply by willing it. At the same time, I have a sense that I can control some aspects of my awareness by my will, that I am, at least in part, subject to laws of pure reason that are not explicable in terms of the causal laws of nature. Kant's transcendental philosophy may be looked at, indeed, should be viewed as an exercise in critical self-reflection on the idea of having a self in relation to the world, and to other selves. The idea of a self is, inherently, the idea of a being with finite powers of willing. The idea I have of myself as a self is inextricably linked with the idea of there being something that is not myself; while, at the same time, awareness of something that is not myself only arises when I am aware of, have the sense that, I am distinct from and exist in some way independently of that which limits the power of my willing. This is precisely the epistemic predicament in which hope functions; hope captures, as has been analysed in more detail in Part 2, this experience of having a positive attitude towards an open framework of possibilities that defy my attempts to grasp and control them.

Now, if this is correct, Kant's transcendental philosophy should be taken, as a whole, to be an analysis of the dialectic between my phenomenological sense that there is a world independent of myself, of which I am at least a part, which I must suppose is governed by universal natural causes and my phenomenological sense that I am able to act according to laws of pure practical reason (see also Lutz 2010, 2012). In short, it is a phenomenology of hope. But, as such, it cannot purport to tell us (to establish) whether or not there is a world that exists independently of my phenomenological awareness of it, nor whether that world in itself is wholly determined, governed by pure chance, or in accordance with the laws of freedom or some combination of these. Nevertheless, rational reflection on how finite beings become selfconscious cannot get away from the fact that reason produces the idea that we are bound by the moral law, and that the world ought to be ordered in ways consistent with what reason prescribes. This cannot be denied for the simple reason that to do so involves the use of the very thing the efficacy of which would be denied. Our suggestion is that reason, in demanding consistency, demands a view of the status of reason that simultaneously recognizes these ultimate limitations of reason, yet, at the same time opens up a space for action (both theoretical and practical) to be meaningful for us, for it to have a point.

The things that Kant himself has to say about what transcendental philosophy can establish are ambivalent, and, remarkably, he employs precisely the terms he developed in discussing hope to address large-scale issues referring to transcendental philosophy as a whole. The conclusion that Kant draws to $\mathrm{CPrR}$ is, perhaps, one of the clearest indications of his intentions in this regard. According to Kant, the idea that the world is governed by universal natural causes, threatens to negate the idea that I have any value in myself, which is most dramatically presented to me when I contemplate the vastness of space and time and think that I might just be a speck of matter in the cosmos. On the other hand, my awareness of the moral law, the fact that reason in its practical use requires me to assent to a categorical imperative, requires me to assent to the idea that the cosmos is inherently meaningful (5:161-162). Kant here uses the epistemic notions that we encountered in his discussion of hope: These experiences can stimulate, a 'Nachforschung'/'inquiry', even though, strictly speaking, an inquiry is impossible; the idea of a consistent determination of my existence under purposes makes it possible to 'infer' (which is a rather too strongly logical translation of the far more open German 'abnehmen') a life-form that transcends the realm of sense experiences.

The conclusion of $C P r R$ combines a threat and a promise. The problem is that these are not equally forceful for Kant. He maintains that the fact that I can contemplate the vastness of the cosmos at all and perceive the threat it poses to the cosmological meaningfulness of my 
existence (and, he might have opined, that I have the idea of a wholly material world only because I experience limitations to my will), means that primacy must be accorded to the promise generated by pure practical reason. Because Kant holds that pure practical reason requires me to suppose that $\mathrm{I}$ have a free will, etc., the consequence is that I am required to have faith that these things are real. However, if what we are suggesting is sound, then, to put it bluntly, the idea of the moral law ought not to be separated from that of the categorical imperative, and must be seen to be grounded (have its ratio essendi) in the fear that my being has no value, coupled with the hope that it does have value. ${ }^{20}$ If we view the moral law as the law of this hope and fear, this integrates the finiteness of man with his supersensible dimensions, but within one phenomenon (see also Stratton-Lake 1993). ${ }^{21}$

Consequently, the essence of being human is not simply that one has the capacity for autonomy, in one's capacity for agency. It resides in the phenomenology of being a vulnerable agent. And this is a being who hopes and fears. It is the capacity for hope (for the efficacy of reason in cosmological matters) and fear (that reason might have no such efficacy) that is the ultimate source of meaning, and not merely meaning that can motivate action. But in the latter regard, human beings are to be seen as having dignity, a moral worth, precisely because they are hoping and fearing beings.

\section{Concluding Remarks}

The position presented in Part 3 is no more than a sketch. To justify it fully requires much more work. Parts of the argument have been developed fully elsewhere (see especially Beyleveld 2012 and 2013a), but we admit that more needs to be done. So we put forward our thesis more as a suggestion or hypothesis for further investigation, and this is the thesis that the power of judgment does not provide us with reason to believe that the cosmos is ordered as a unified system compatible with the categorical imperative and its postulates, but requires us to hope that it is, and no more.

Open Access This article is distributed under the terms of the Creative Commons Attribution License which permits any use, distribution, and reproduction in any medium, provided the original author(s) and the source are credited.

\section{References}

Axinn S (1994) The logic of hope: extensions of Kant's view of religion. Rodopi, Amsterdam, Atlanta GA Beyleveld D (2012) Hope and belief. In: Jenkins RJ, Sullivan E (eds) Philosophy of mind. Nova, New York, pp $1-36$

Beyleveld D (2013a) Williams' false dilemma: how to give categorically binding impartial reasons to agents. J Moral Philos 10:204-226

Beyleveld D (2013b) Korsgaard v. Gewirth on Universalization: Why Gewirthians are Kantians and Kantians Ought to be Gewirthians. J Moral Philos. doi:10.1163/17455243-4681026, Fast Track Article:1-24

Breitenbach A (2009) Die Analogie von Vernunft und Natur. Eine Umweltphilosophie nach Kant. De Gruyter, Berlin, New York

\footnotetext{
${ }^{20}$ It follows that Kant must be wrong when he claims (e.g., 4:447; 5:29) that free will and the moral law are reciprocal. In our opinion, it also follows, on Kant's methodological premises, that the categorical imperative is not Kant's Formula of Humanity, but Alan Gewirth's Principle of Generic Consistency (see Beyleveld 2013b). ${ }^{21}$ This statement needs to be carefully related to a passage in Religion where Kant states that 'mere fear and hope' cannot be sufficient for founding a philosophically significant form of faith (7:42).
} 
Fichte JG (1978) Vorlesungen über die Wissenschaftslehre gehalten zu Jena im Winter 1798-1799. In: Fiche JG, Gesamtausgabe vol. IV,2. Frommann-holzboog, Stuttgart-Bad Cannstatt

Förster E (2002) Die Bedeutung von $\S \S 76,77$ der Kritik der Urteilskraft für die Entwicklung der nachkantischen Philosophie. Teil II. Z Philos Forsch 56:321-345

Grimm J, Grimm W (1885) Deutsches Wörterbuch. Entry "Leitfaden". http://woerterbuchnetz.de/DWB/?sigle= DWB\&mode $=$ Vernetzung\&lemid $=$ GL04639

Guyer P (1996) Kant and the experience of freedom. Essays on aesthetics and morality. CUP, Cambridge

Guyer P (2005) Kant's system of nature and freedom. Selected Essays. Clarendon, Oxford

Kant I (1900sqq.) Gesammelte Schriften. Reimer/de Gruyter, Berlin

Kant I (1995sqq.) Cambridge Edition of the Works of Immanuel Kant, Guyer P, Wood AW (eds) CUP, Cambridge

Lutz R (2010) Hoffnung bei Kant. Reflexionen zur Reichweite endlicher Vernunft. In: Schuster J (ed) Zur Bedeutung der Philosophie für die Theologische Ethik. Herder, Fribourg, Freiburg i. Br, Wien, pp 221-241

Lutz R (2012) Der hoffende Mensch. Anthropologie und Ethik menschlicher Sinnsuche. Francke, Tübingen

Maly S (2012) Kant über die symbolische Erkenntnis Gottes. De Gruyter, Berlin, Boston

Peters CH (1993) Kant's philosophy of hope. Peter Lang, New York

Stratton-Lake P (1993) Reason, appropriateness and hope: sketch of a Kantian account of a finite rationality. Int J Philos Stud 1(1):61-80

Wiesche T (2012) Moral und Glück. Hoffnung bei Kant und Adorno. DZPhil 60:49-71

Williams B (1985) Ethics and the limits of philosophy. Fontana, London

Wimmer R (1990) Kants kritische Religionsphilosophie. De Gruyter, Berlin, New York 